\title{
IS LEISHMANIASIS ENDEMIC ON THE ISLAND OF MINORCA (SPAIN) ? A HUMAN VISCERAL CASE AFTER LIVING 13 YEARS IN MINORCA
}

\author{
PORTÙS M.*, GALLEGO M.*, SEGUI M.G.*, SOLE J.**
}

\section{Summary :}

Ecoepidemiological studies performed in Minorca |Balearic Islands) seem to show that leishmaniasis is not endemic in this island, even in the presence of the vector. All cases of leishmaniasis in man or dog diagnosed in the island seem to come from other Spanish regions. A recent case of human visceral leishmaniasis in a man who had not left Minorca for 13 years calls into question this assumption or the time that Leishmania may persist asymptomatic in the host.

KEY WORDS : Leishmaniasis. Minorca. MOTS CLES : Leishmaniose. Minorque.

coepidemiological studies performed since 1988 on leishmaniasis in Minorca (Balearic Islands) support the opinion that the active transmission of the parasite does not occur, in spite of the presence in the island of all the elements in the cycle: parasite, vector and reservoir. Nevertheless, leishmaniasis is present at a high endemicity in other Balearic islands such as Majorca and Ibiza (Matas and Rovira, 1989)

In the summer of 1988, 751 dogs (total census of the island was 2729) were serologically studied as to the presence of anti-Leishmania antibodies. The animals were sampled from all over the island. A further 92 dogs have been studied since then, for symptoms compatible with leishmaniasis. Anti-Leishmania antibodies were detected in 8 dogs, 3 asymptomatic and 5 with symptoms. Culture was carried out in three cases and only one was positive. The strain isolated was identified as Leishmania infantum ZMON-1, by the Laboratoire d'Ecologie médicale of Montpellier.

Case histories of the 8 seropositive dogs showed that all of them had been imported to the island from other Spanish places, one from Badajoz, three from Barcelona, three from Madrid and one from Majorca, in all of which leishmaniasis is endemic.

There are only two records of human leishmaniasis in the island's hospital : a visceral case in a 23 year-old woman from Almeria, in 1983, and a cutaneous case in a young man from Valencia, in 1985.

Entomological studies showed the presence of two species of Phlebotomus in the island : P.perniciosus

\footnotetext{
* Unitat de Parasitologia, Facultat de Fármacia, Universitat de Barcelona. Avda. Diagonal, 08028 Barcelona.

** Hospital Verge del Toro, c/Barcelona, 07701 Máo (Menorca).
}

Résumé : LA LEISHMANIOSE EST-ELLE ENDÉMIQUE DANS L'ILE DE MinORQUE? UN CAS DE LEISHMANIOSE VISCÉRALE CHEZ UN HOMME N'AYANT PAS QUITTÉ L'ILE DEPUIS 13 ANS.

Les études éco-épidémiologiques faites dans l'île de Minorque (Baléares) semblent indiquer que la leishmaniose n'est pas endémique dans cette ille de la Méditerranée, malgré la présence du vecteur. Tous les cas de leishmaniose humaine ou canine diagnostiqués dans cette île paraissent importés d'autres régions de l'Espagne. Un récent cas de leishmaniose viscérale humaine chez un homme qui n'avait pas quitté l'île pendant 13 ans remet en cause cette donnée ainsi que le temps pendant lequel Leishmania peut demeurer asymptômatique chez l'homme.

and $P$. sergenti. Only the former showed sufficient density, in some places, to be considered as a potential vector for leishmaniasis. The highest density observed in one station was 456 specimens $/ \mathrm{m}^{2}$ of castor oil-soaked paper, in September 1989. In October 1991, 214 P. perniciosus females were dissected in order to establish their physiological age and the rate of parasitism by flagellates. This represents the total captures during six consecutive nights with 10 CDC light traps, in places where the highest sandfly density had been obtained in previous studies. 136 were nulliparous, 47 were parous and 31 had developing eggs. Gut examination was negative for flagellates in all of them.

Although relatively few females were dissected, the proportion of parous females was notably low, as they were at the end of their activity season, when the population decreases and the proportion of parous females is expected to be higher (Guilvard et al., 1980). Studies on the biology of sand flies in the island are in course, in order to understand the reasons for this probable lack of endemicity ; tentatively, we suppose that the wind, normally present in Minorca, could reduce the life span of females and parasite transmission.

In March 1991 a 44 year-old man was admitted for fever, anorexia, asthenia and loss of weight. The patient had not left Minorca since 1978 when he travelled to Costa Brava.

He had hepatomegaly, painful to palpation, slight splenomegaly and absence of lymphadenopathy. Pancytopenia and gammopathy were also present. A chest X-ray was normal and the abdominal echography revealed hepatosplenomegaly and a hepatic cyst. Serological tests for Toxoplasma, HIV, B and C hepa- 
titis viruses, infectious mononucleosis, boutonneuse fever and cytomegaloviruses were negative. Bone marrow aspirate showed the presence of Leishmania. Treatment was started with pentavalent antimonials and the patient improved rapidly.

The presence of cryptic forms of leishmaniasis in endemic areas has been demonstrated by various authors (Pampiglione et al., 1974 ; Badaró et al., 1986 ; Alvar et al., 1992). The high number of human visceral leishmaniasis in AIDS patients also suggests that many could be reactivations of cryptic forms. However, it is not known how long the parasite persists in the host.

The recent active transmission of the disease in this patient remains a possibility, as the vector is present in the island ; nevertheless, all those epidemiological data suggest that the case could be a reactivation of a Leishmania infection acquired 13 years before.

\section{ACKNOWLEDGEMENTS}

tudies were supported by Dirección General de Investigación Científica y Técnica (DGICYT), project SAL90-960.

\section{REFERENCES}

Alvar J., Gutierrez-Solar B., Molina R., Lopez-Velez R., Garcia-Camacho A., Martinez P., Laguna F., Cercenado E. \& Galmes A. : Prevalence of Leishmania infection among AIDS patients. The Lancet, 1992, 339, 1427.

Badaro R., Jones T.C., Carvalho E.M., Sampaio D., Reed S.G., Barral A., TeIXeIra R. \& Johnson Jr. W.D. : New perspectives on a subclinical form of visceral leishmaniasis. The Journal of Infectious Diseases, 1986, 154, 1003-1011.

Guilvard E., Wilkes T.J., Killick-Kendrick R. \& Rioux J.A. : Ecologie des leishmanioses dans le sud de la France. 15. Déroulement des cycles gonotrophiques chez Phlebotomus ariasi et Phlebotomus mascittii en Cévennes. Corollaire épidémiologique. Annales de Parasitologie humaine et comparée, 1980, 55, 659-664.

Matas-Mir B. \& Rovira-Alos J. : Estudio epidemiológico de la leishmaniosis canina en la Isla de Mallorca. Publicacions de la Conselleria de Sanitat $i$ Seguretat Social del Govern Balear, 1989, 110 p.

Pampiglione S., Manson-Bahr P.E.C., Giungi F., Giunti G., Parenti A. \& Trotti G.C. : Studies on Mediterranean leishmaniasis. 2. Asymptomatic cases of visceral leishmaniasis. Transactions of the Royal Society of Tropical Medicine and Hygiene, 1974, 68, 447-453.

Accepté le 12 janvier 1994 